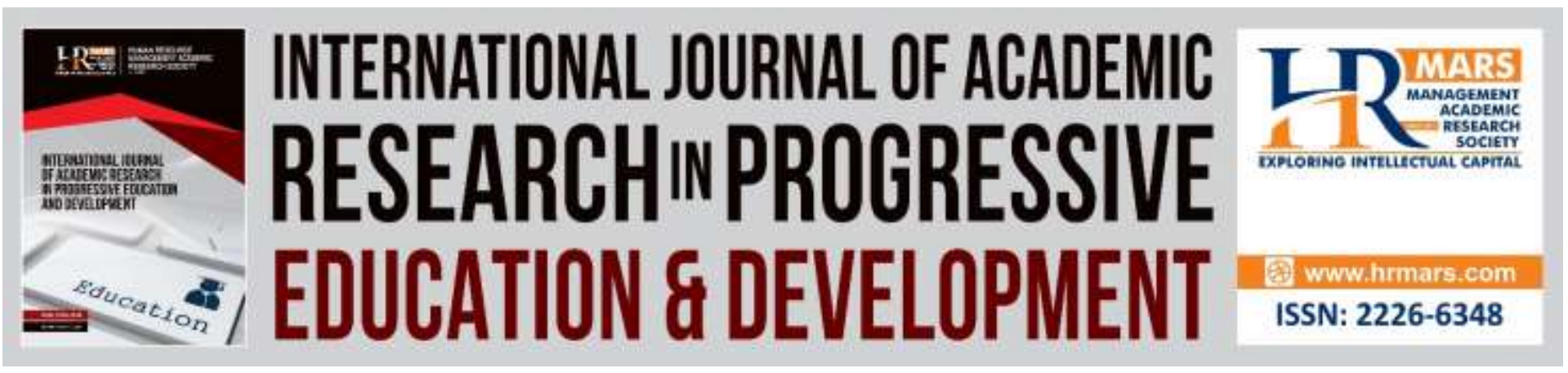

\title{
Assessment Level Implementation of School Improvement Specialist Coaches Program: Efficient Teaching Coaches Features
}

\section{Salefah Mat Salleh and Norasmah Othman}

To Link this Article: http://dx.doi.org/10.6007/IJARPED/v8-i2/5690

DOI: $10.6007 /$ IJARPED/v8-i2/5690

Received: 23 March 2019, Revised: 29 April 2019, Accepted: 03 May 2019

Published Online: 10 May 2019

In-Text Citation: (Salleh \& Othman, 2019)

To Cite this Article: Salleh, S. M., \& Othman, N. (2019). Assessment Level Implementation Of School Improvement Specialist Coaches Program: Efficient Teaching Coaches Features. International Journal of Academic Research in Progressive Education and Development, 8(2), 142-158.

\section{Copyright: (C) 2019 The Author(s)}

Published by Human Resource Management Academic Research Society (www.hrmars.com)

This article is published under the Creative Commons Attribution (CC BY 4.0) license. Anyone may reproduce, distribute, translate and create derivative works of this article (for both commercial and non-commercial purposes), subject to full attribution to the original publication and authors. The full terms of this license may be seen at: http://creativecommons.org/licences/by/4.0/legalcode

Vol. 8(2) 2019, Pg. 142 - 158

Full Terms \& Conditions of access and use can be found at http://hrmars.com/index.php/pages/detail/publication-ethics 


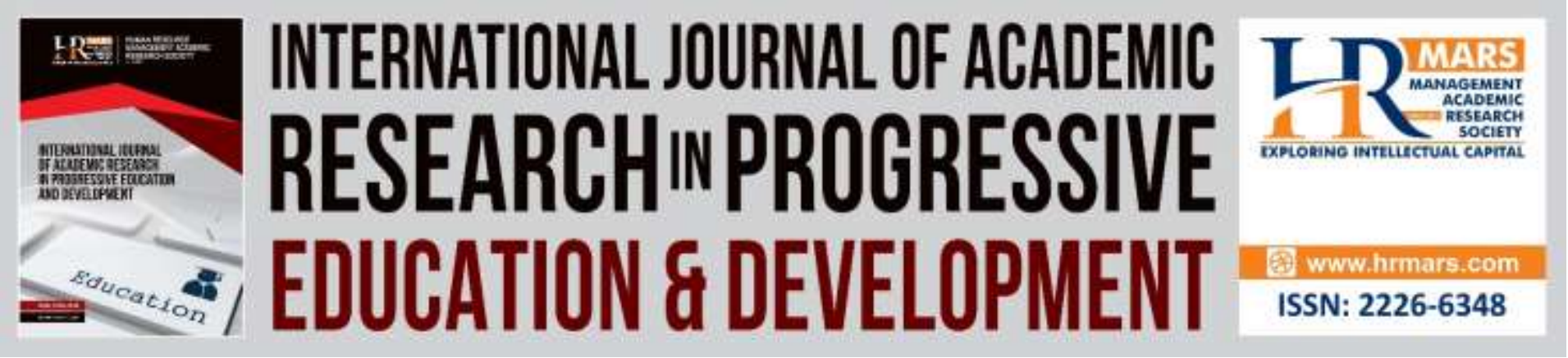

\title{
Assessment Level Implementation Of School Improvement Specialist Coaches Program: Efficient Teaching Coaches Features
}

\author{
Salefah Mat Salleh and Norasmah Othman \\ Faculty of Education, Universiti Kebangsaan Malaysia, Malaysia
}

\begin{abstract}
This study was conducted to identify the teachers' perceptions towards the implementation of the School Improvement Specialist Coaches (SISC+) program from SISC+ features as an effective teaching guide. SISC+ is assigned to guide teachers in low-performing schools and are in band 6 and band 7. So SISC+ needs to serve as an efficient teaching coaches so that the objective of setting up the SISC+ program can be fully achieved. The methodology of this study was quantitative using five-point Likert scale questionnaires and 400 teachers were involved in the study. The data obtained were analyzed using the IBM SPSS version 22.0 software with reference to mean, percentage and standard deviation. The findings show that overall SISC+ features are at a high level when it is able to meet the needs of effective counselors in terms of roles, knowledge, feedback, personal characteristic and role model. In conclusion, SISC+ needs to meet the requirements as an efficient teaching coaches and in accordance with the guidelines set so that more positive effects will be obtained.
\end{abstract}

Keywords: Role, Knowledge, Feedback, Personal Characteristic, Role Model.

\section{Introduction}

The teaching coaching program has been implemented since the beginning of the 21st century in the United Kingdom, the United States and Australia (Nieuwerburgh, 2012) and has become the primary basis for initiating school improvement initiatives, improving teaching quality of teachers and student achievement (Nieuwerburgh \& Campbell, 2015). The National College for School Leadership in the United Kingdom explains that teaching guidance is an essential skill for enhancing teacher professionalism (Creasy \& Paterson, 2005 in Nieuwerburgh \& Campbell, 2015). The International Reading Association (IRA) is an organization that provides support to individuals and organizations around the world to illustrate that teaching counselors are individuals who help teachers improve teaching practices (IRA, 2004). In the United States, teaching instruction was introduced in major areas such as Boston and New York and continued to extend to other cities in 2001 (Pharrams, 2016). The goal is to help teachers improve their skills and effective learning skills in the classroom (Denton, 2003; Dole, 2004). 
INTERNATIONAL JOURNAL OF ACADEMIC RESEARCH IN PROGRESSIVE EDUCATION AND DEVELOPMENT

Vol. 8, No. 2, 2019, E-ISSN: 2226-6348 @ 2019 HRMARS

In Malaysia, an efficient teaching coaches program named School Improvement Specialist Coaches Plus ( $\mathrm{SISC}+$ ) is expected to enhance the quality of teaching and learning among teachers (Ministry of Education Malaysia (MOE), 2013). Through the School Development Program under the GTP 1.0 sub NKRA initiative, the government has appointed full-time efficient teaching coaches known as SISC+ (MOE, 2015) officers. The role of SISC+ is to conduct school-guided tours, ensure the implementation of MOE policies and programs in schools, improve professionalism, knowledge, skills and attitudes, and plan and coordinate the implementation of teacher training in their respective districts (MOE, 2017). The teachers selected to hold SISC+ positions are largely among excellent teachers (MOE, 2015). Excellent teachers are chosen for their knowledge, skills, expertise, dedication and motivation in performing their duties and responsibilities especially in teaching (MOE, 2015). The choice of SISC+ among teachers is important because co-supervisor guidance can increase self-esteem to teach and support psychological needs (Peter \& Richard, 2017). Even according to Knight (2007), this situation allows teachers to effectively master their duties. A professional development strategy known as teaching coaches guidance generally involves specialists in the field of specific subjects that work closely with small groups of teachers to improve practice in the classroom and ultimately lead to student achievement (Russo, 2007).

Through the SISC+ program, it is expected to have a significant impact on the way teachers gain information on subject matter content, acquire new teaching strategies and skills, working with colleagues and the ability to analyze and plan their professional learning.

\section{Problem Statement}

Teachers play an important role not only in the formation of society, but also in the development of the nation. The SISC+ program was introduced to reduce the leakage of information in the delivery of the curriculum and improve teacher professionalism. Therefore, the excellent teachers who are considered subject teachers are the most appropriate people to help teachers in pedagogy and thereby improve teacher professionalism. However, there is also an issue of expertise in the field of teaching to guide teachers as many SISC+ are not teachers excel in subjects. Many excellent teachers who are not interested in becoming SISC+ (MOE, 2014) officers. This causes the opportunity to be opened to other non-specialist teachers in the subject. According to the SISC+ Implementation Study Report (MOE, 2014), 233 people have been appointed as SISC+ in Kedah and Sabah, only 51 (21.9\%) of them are excellent teachers. Hence, the authority of SISC+ officers is often disputed by teachers and school administrators (MOE, 2014). The situation is also in line with Neufeld's (2003) study that one of the challenges in the implementation of teaching coaching in the Boston and San Diego districts is difficult to get qualified efficient teaching coaches and experts in subjects.

The lack of courses and training provided also affects the effectiveness of SISC+ staff work (MOE, 2014). Training is an effort to increase the knowledge, skills and behaviors required in implementing job scope matters. Lack of training leads to efficient teaching coaches cannot performed effectively (Natale et al., 2013). Killion and Harrison (2005) stated that teaching coaches needed skills in three key areas, teaching expertise (Burkins \& Ritchie, 2007; Denton \& Hasbrouck, 2009; Feger, Woleck \& Hickman, 2004), interpersonal skills (Burkins \& Ritchie, 2007; Feger, Woleck \& Hickman, 2004), and communication skills (Neufeld \& Roper, 2003). Teaching should have efficient teaching coaches and knowledge in the field of work (Burkins \& Ritchie, 2007; Denton \& 
Hasbrouck, 2009; Feger, Woleck \& Hickman, 2004; Killion \& Harrison, 2005) and the ability to effectively collaborate with mentored teachers (CSTP, 2009). Therefore, it is important to choose a capable counselor and be given appropriate training (Steiner \& Kowal, 2007).

When lack of training among SISC+, there is also a lack of knowledge to coach teachers. The situation will create negative perceptions among teachers, giving the impression that SISC+ knowledge is the same as those who receive coaching (MOE, 2014). If the instructor does not have the knowledge in the field of work, it will affect teachers' perceptions and the program goals are not fully achieved (Erawan, 2014; Johnson \& Donaldson, 2007; York-Barr \& Duke, 2004). As an efficient teaching coaches, SISC+ should have the knowledge and a high level of content of pedagogy (Borman \& Feger, 2006; Denton \& Hasbrough, 2009; Killion \& Harrison, 2005).

Changes in education are mostly intended to narrow the gap between the traditional capabilities of the education system and rapidly changing world development (Hallinger \& Kantamara, 2000). However, there are still less clear teachers with the changes in the education system (Uline, 2001). This led to the assumption that presence of SISC+ officers into the school was only looking for teachers' weakness (MOE, 2014; Syahiran et al., 2016) and even more comfortable practicing old methods using textbooks, notes or writing on whiteboards (Radhiah, Rasid \& Azhar, 2016). It will affect the effectiveness of the SISC+ task to guide the teacher and be one of the major challenges to all teaching guides in other countries (Borman \& Feger, 2006; Knight, 2011; Katzenmeyer \& Moller, 2009; Pharrams, 2016; Richard, 2003; Poglinco et al., 2003; Steiner \& Kowal, 2007). A program should take into account the needs, interests and burden of teachers involved and flexible (Erawan, 2014). The efficient teaching coaches needs to analyze individual teachers' problems by coaching them to help solve problems and not just talk or sell ideas (Erwan, 2014). It is important to clarify the role of efficient teaching coaches so that teachers understand the goals they want to achieve (Heineke \& Polnick, 2013; Knight, 2007; Wren, 2005). Efficient teaching coaches become more effective when teachers agree to be guided (Joyce \& Showers, 2002) and apply new teaching practices in the classroom (Archibald, et al., 2011; Darling-Hammond et al., 2009).

In conclusion, the SISC+ program needs to be assessed so that its deficiencies and weaknesses can be improved and made improvements so that the objective of its establishment can be achieved as expected. Evaluation of program implementation should be conducted to ensure that the program is really necessary (Fatimah, 2009).

\section{Problem Statement}

Coaching at school level is a form of leadership practice that emphasizes the effectiveness of the learning and teaching process (Jamaliah \& Norhasimah, 2006; Muijs \& Harris, 2007). Efficient teaching coaches among teachers are to increase the motivation of colleagues to continuously work on innovative learning and teaching as well as performing their duties more effectively (Busher \& Harris, 2000; Day 2007; Shukri, 2004).

Hargreaves and Fullan (2000) argue that the field of teaching requires coaching and training in order to provide sufficient exposure and experience to teachers about the teaching profession as well as challenges to be encountered. Efficient teaching coaches also requires a high commitment from teachers in the implementation of teaching by reflecting on improvements, always discussing with students about problems encountered, identifying and solving problems 
related to teaching (Edwards et al., 2002). The efficient teaching coaches appointed among teachers are those who have been identified for their knowledge and skills in parallel with the program (Chadd \& Anderson, 2005).

The features of the efficient teaching coaches that should be available to the coach are the role of the coach, the coach knowledge, feedback, personal characteristic and role models (Abiddin, 2006; Bhojani, 2007; Hudson et al., 2005; McAlack, 2006). The role of efficient teaching coaches is to assess the guided persons (Smith 2000; Hudson et al., 2005) and provide motivation and motivation to the guided man (Skippington, 2002). From the point of knowledge, the efficient teaching coaches must be knowledgeable in the field of work (Gray \& Smith, 2000; Fawcett, 2002; Ramage, 2003), able to teach and be a good presenter (Gray \& Smith, 2000). Any feedback should be made as soon as possible in order to avoid diminished initiatives that are guided to make improvements in the future (Kwong, 2001). Providing feedback is the process of responding to one's acceptance and understanding to others (Sharp et al., 2005). Efficient teaching coaches should face the challenge positively, be patient and use effective methods when faced with stress, highlighting the nature of knowledgeable people and providing support to guided people without expecting a return (Fawcett, 2002; McKinley, 2004). Efficient teaching coaches who have a good role model are always professional in performing their duties as they are always looked upon by guided ones (Bhojani, 2007; Boud \& Solomon, 2001; Gray and Smith, 2000; Hudson et al., 2005).

\section{Purpose and Objectives of Study}

Perceptions from guided teachers are important to see the effectiveness of the SISC+ program. Therefore, this study is conducted to evaluate the implementation of the SISC+ program from SISC+features as an efficient teaching coaches. While the objective of the study is to identify the level of SISC+ features, namely the role, knowledge, feedback, personal traits and SISC+ officers' examinations as efficient teaching coaches in accordance with the guided teacher's perception.

\section{Methodology}

This study was conducted to identify the level of implementation of the School Improvement Specialist Coaches (SISC+) program from the SISC+ features as an effective teaching guide. This study uses a questionnaire as an instrument. The construction of questionnaire items in this study is adapted for teachers involved with the SISC+ program, which refers to the problems and literature highlights of the effective guidance features of Abiddin (2006), Bhojani (2007), Hudson et al. (2005) and McAlack (2006). It is also taken into account based on the Standard Guru Malaysia Model (MOE, 2010) and the Regional Transformation Program Management Guide (MOE, 2017). Likert scale 5 stage approval was developed to represent the participants by responding to the stage of approval given. The results were analyzed using the IBM SPSS version 22.0 software.

Questionnaire items need to be tested for their use so that the instruments used are appropriate and able to answer the research questions. In this study, reliability of items and individuals is determined by Rasch measurement method. The reliability of the item in this study is 0.85 . Bond and Fox (2007) state that the value above 0.80 is the reliability value of the item received strongly. Likewise, Mohamad Najib (2009) and Sekaran and Bougie (2011) argue that values above 0.80 are considered to be worth the value of Cronbach Alfa. The research instrument 
is also spread evenly from the toughest item to the simplest item, considered stable and consistent if it is repeated. While the value of reliability of individual abilities is 0.99 and is at a value above 0.94 which is categorized as excellent (Fisher, 2007). The findings of the individual reliability index indicate that the sample used is sufficient and capable of representing the characteristic to be tested.

The sampling in this study was comprised of Malay Language, English and Mathematics teachers involved with the SISC+ program throughout the country, totaling 400 people. The number of samples is based on sample size formula Cohen (2010).

The researcher carried out the assessment of the mean score based on the assessment by the Education Policy Planning and Research Division (2006), by interpreting the mean SISC+ characteristics in this study as shown in Table 1.

Table 1. Interpretation mean

\begin{tabular}{|c|c|}
\hline Mean Score Range & Interpretation \\
\hline 1.00 to 1.80 & Very low \\
\hline 1.81 to 2.60 & Low \\
\hline 2.61 to 3.40 & Moderate \\
\hline 3.41 to 4.20 & High \\
\hline 4.21 to 5.00 & Very High \\
\hline
\end{tabular}

Source: Educational Policy Planning and Research Division (2006)

\section{Result and Discussion}

The level of SISC+ features as an efficient teaching coaches.

Based on Table 2, SISC+ characteristics are found to be high (mean= 3.50, standard deviation= 0.19). The analysis shows that SISC+ has qualified as an efficient teaching coaches (Abiddin, 2006; Bhojani, 2007; Hudson et al., 2005; McAlack, 2006). However, when analyzing each of the features of effective supervisors, SISC+ knowledge is at a moderate level (mean= 3.36, standard deviation= 0.69). SISC+ knowledge at a moderate level will affect the effectiveness of SISC+ mentoring as an efficient teaching coach. Whereas, the role, feedback, personal characteristic and SISC+ role model are at a high level. As evidence, the role (mean= 3.55, standard deviation= 0.41 ), feedback (mean=3.43, standard deviation=0.44), personal characteristic $($ mean= 3.52 , standard deviation $=0.30$ ) and role model (mean $=3.54$, standard deviation $=0.74)$. Whereas the standard deviation value for all items is less than one. This finding shows that the item distribution is approaching mean (Jackson, 2006; Pallant, 2007). The small standard deviation value shows the distribution of respondents' perceptions of SISC+ characteristics as teaching coach is small. 
INTERNATIONAL JOURNAL OF ACADEMIC RESEARCH IN PROGRESSIVE EDUCATION AND

DEVELOPMENT

Vol. 8, No. 2, 2019, E-ISSN: 2226-6348@ 2019 HRMARS

Table 2. Level of SISC+ Features in SISC+ Implementation

\begin{tabular}{|l|c|c|c|}
\hline \multicolumn{1}{|c|}{ SISC+ Features } & Mean Score & Standard deviation & Interpretation \\
\hline Role & 3.55 & 0.41 & High \\
\hline Knowledge & 3.36 & 0.69 & Moderate \\
\hline Feedback & 3.43 & 0.44 & High \\
\hline Personal characteristic & 3.52 & 0.30 & High \\
\hline Role Model & 3.54 & 0.74 & High \\
\hline & $\mathbf{3 . 5 0}$ & $\mathbf{0 . 1 9}$ & High \\
\hline
\end{tabular}

The role of SISC+ as an efficient teaching coaches.

The overall mean score of SISC+ role as efficient teaching coaches is at high level (mean= 3.55 , standard deviation= 0.41 ). The findings show that the most effective role of SISC+ is motivating to improve the performance of the coach teacher. SISC+ needs to be trained in motivating because the teacher's work is not limited to teaching in the classroom alone, even covering a variety of professional activities at school level (OECD, 2009). Effective motivation given by SISC+ can reduce stress and teachers can complete the task in a positive way. With a positive mindset among teachers, there will be a strong self-esteem for every problem and complexity in carrying out the task. SISC+ also needs support and motivation that can reduce teacher's concerns when faced with frustration or uncertainty during the planned teaching activities. This finding is consistent with Skippington's (2002) opinion that one of the role of efficient teaching coaches is to motivate the quality of work to be improved. Additionally, it can have a positive impact on the guided individuals (Burwell \& Chen, 2006).

The findings also show that SISC+ has successfully established a good relationship that can convince teachers. Thus, SISC+ has successfully influenced teachers to tell the problem faced by teaching. The success of SISC+ establishing good rapport is an early step in building self-confidence of teachers to accept the presence of SISC+ as an efficient teaching coaches. This finding is in line with Andrews (2002) opinion that efficient teaching coaches need to be concerned with the problems faced by guided individuals. Studies conducted by Olivia and Pawlas (2004); and Schmidt (2003) point out that effective teaching guidance practices also have an impact on guided individual emotions. SISC+ is committed to building a good relationship by understanding the problems faced by teachers. This situation is important so that the teacher is always calm by giving a positive first impression and can build a convincing atmosphere and form the warmth (Adiliah \& Haliliah, 2002; Shah, 2009). According to the principle of School-Based Program, a program should take into consideration the needs, interests and burden of teachers involved and flexible (Erawan, 2014).

In addition, the role of SISC+ to guide teachers to solve problems in teaching needs to be further improved. The findings show that almost $30 \%$ of respondents give a perception that SISC+ is very rare in providing guidance to identify actions that need to be taken to solve the problems faced in teaching. SISC+ should not only show concern over the problem, but also have to master the way to guide teachers to find solutions to the problem. As an efficient teaching coaches, SISC+ needs to analyze individual teachers' problems and needs by guiding them to help solve problems rather than just talking or selling ideas (Erwan, 2014). In this regard, SISC+ also needs to play a role as a guide by providing advice and counseling as well as sharing knowledge (Abiddin, 2006). 
As an efficient teaching coaches, SISC+ should also be smart to play a role in challenging teachers to improve the quality of teaching and encourage teachers to express the goals they want to achieve for each lesson. However, the findings show that almost $50 \%$ of respondents are of the opinion that SISC+ only occasionally performs the role. SISC+ should play its role in guiding teachers by actively helping to achieve goals related to career quality improvement (Skippington, 2002; Horne, 2003).

In general, data analysis in this study explains that the role of SISC+ as an efficient teaching coaches has fulfilled one of the features that should be present in effective counselors as suggested by Gray \& Smith, 2000; Hudson et al., 2005; Abiddin, 2006; McAlack, 2006; Bhojani, 2007).

Table 3. Frequency and Percentage for Role Aspect

\begin{tabular}{|c|c|c|c|c|c|c|}
\hline \multirow[b]{2}{*}{ No } & \multirow[b]{2}{*}{ Role Aspect } & \multicolumn{5}{|c|}{ Frequency and Percentage (\%) } \\
\hline & & $\mathbf{N}$ & VR & $\mathbf{S}$ & Mt & A \\
\hline 1 & $\begin{array}{l}\text { to guide me to identify the actions } \\
\text { that need to be taken to solve the } \\
\text { problems faced in teaching. }\end{array}$ & - & $\begin{array}{c}3 \\
(8.0 \%)\end{array}$ & $\begin{array}{c}195 \\
(48.8 \%)\end{array}$ & $\begin{array}{c}174 \\
(43.5 \%)\end{array}$ & $\begin{array}{c}23 \\
(7.0 \%)\end{array}$ \\
\hline 2 & $\begin{array}{l}\text { challenging me to always strive to } \\
\text { improve the quality of my teaching. }\end{array}$ & - & $\begin{array}{c}3 \\
(8.0 \%) \\
\end{array}$ & $\begin{array}{c}188 \\
(47.0 \%)\end{array}$ & $\begin{array}{c}145 \\
(36.3 \%)\end{array}$ & $\begin{array}{c}64 \\
(16.0 \%) \\
\end{array}$ \\
\hline 3 & $\begin{array}{l}\text { asks me to state the goals to be } \\
\text { achieved in each lesson being } \\
\text { conducted. }\end{array}$ & - & $\begin{array}{c}111 \\
(27.8 \%)\end{array}$ & $\begin{array}{c}142 \\
(35.5 \%)\end{array}$ & $\begin{array}{c}81 \\
(20.3 \%)\end{array}$ & $\begin{array}{c}66 \\
(16.5 \%)\end{array}$ \\
\hline 4 & $\begin{array}{l}\text { giving motivation to improve my } \\
\text { work performance. }\end{array}$ & - & - & $\begin{array}{c}155 \\
(38.8 \%)\end{array}$ & $\begin{array}{c}149 \\
(37.3 \%)\end{array}$ & $\begin{array}{c}96 \\
(24.0 \%)\end{array}$ \\
\hline 5 & $\begin{array}{l}\text { encouraging me to tell you about the } \\
\text { problems faced in teaching. }\end{array}$ & - & $\begin{array}{c}90 \\
(22.5 \%)\end{array}$ & $\begin{array}{c}130 \\
(32.5 \%)\end{array}$ & $\begin{array}{c}89 \\
(22.3 \%)\end{array}$ & $\begin{array}{c}91 \\
(22.8 \%)\end{array}$ \\
\hline \multicolumn{7}{|c|}{ Role Aspect: Mean 3.55, Standard deviation 0.41.} \\
\hline & VR $=$ Very Rare $\quad S=$ Som & & $\mathrm{Mt}=\mathrm{N}$ & st of the & & Always \\
\hline
\end{tabular}

SISC+ knowledge level as an efficient teaching coaches.

The majority of respondents' perceptions of SISC+ knowledge as an efficient teaching coaches are moderate ( $\min =3.36$, standard deviation= 0.69). This situation illustrates that SISC+ still lacking knowledge to convey and transfer the knowledge to the teacher. This aspect should be given due attention as the effectiveness of the guidance given depends largely on the degree of knowledge that SISC+ officials have. The findings are consistent with the findings of MOE (2014), which is the level of knowledge of SISC+ disputed by the teachers involved with the SISC+ program. An efficient teaching coaches should master the knowledge in the field of work so that the transfer of knowledge and information to the guided individuals can be done effectively (Asiana, 2014; Fadzil \& Jaleel, 2013).

Respondents' perceptions from the SISC+ knowledge point of view as teaching guides illustrate that one of the characteristics of an effective mentor is still in full capacity. It also shows that SISC+ cannot cater for all the effective coaching features as suggested by Gray and Smith (2000), Hudson et al. (2005), Abiddin (2006), Alack (2006) and Bhojani (2007). A study conducted by Gallucci et al. (2010) found that instructors should be given training in the field of work for a 
INTERNATIONAL JOURNAL OF ACADEMIC RESEARCH IN PROGRESSIVE EDUCATION AND DEVELOPMENT

Vol. 8, No. 2, 2019, E-ISSN: 2226-6348 @ 2019 HRMARS

year before performing their duties to ensure that the counseling process is effective. This finding demonstrates the importance of courses or training to enhance knowledge and skills to ensure that the implementation of a program can be carried out properly (Edward, 2000).

Table 4. Frequencies and Percentages of Knowledge Aspects

\begin{tabular}{|l|l|c|c|c|c|c|}
\hline \multirow{2}{*}{ No } & \multicolumn{1}{|c|}{ Knowledge Aspect } & VL & $\mathbf{L}$ & $\mathbf{M}$ & $\mathbf{H}$ & $\mathbf{V H}$ \\
\cline { 2 - 7 } & $\begin{array}{l}\text { knowledge of creative } \\
\text { pedagogical practices. }\end{array}$ & - & 86 & 191 & 83 & 40 \\
$(21.5 \%)$ & $(47.8 \%)$ & $(20.8 \%)$ & $(10.0 \%)$ \\
\hline 2 & $\begin{array}{l}\text { knowledge to integrate ICT } \\
\text { into teaching. }\end{array}$ & - & $\begin{array}{c}76 \\
(19.0 \%)\end{array}$ & $\begin{array}{c}136 \\
(34.0 \%)\end{array}$ & $\begin{array}{c}147 \\
(36.8 \%)\end{array}$ & $\begin{array}{c}41 \\
(10.3 \%)\end{array}$ \\
\hline 3 & $\begin{array}{l}\text { knowledge to apply high-level } \\
\text { thinking skills in teaching in } \\
\text { accordance with the } \\
\text { requirements of the 21st } \\
\text { century. }\end{array}$ & - & $\begin{array}{c}70 \\
(17.5 \%)\end{array}$ & $\begin{array}{c}134 \\
(40.3 \%)\end{array}$ & $(33.5 \%)$ & $(8.8 \%)$ \\
\hline 4 & $\begin{array}{l}\text { knowledge as an expert in } \\
\text { pedagogy. }\end{array}$ & - & $\begin{array}{l}68 \\
(17.0 \%)\end{array}$ & $\begin{array}{c}137 \\
(34.3 \%)\end{array}$ & $\begin{array}{c}101 \\
(25.3 \%)\end{array}$ & $\begin{array}{c}94 \\
(23.5 \%)\end{array}$ \\
\hline
\end{tabular}

$\mathrm{VL}=$ Very Low $\mathrm{L}=$ Low $\quad \mathrm{M}=$ Moderate $\quad \mathrm{H}=$ High $\quad \mathrm{VH}=$ Very High

SISC + feedback level as an efficient teaching coaches.

Overall, the majority of respondents' perceptions of SISC + feedback as an efficient teaching coaches are at high level (mean= 3.43 , standard deviation $=0.44$ ). The feedback level provided by $\mathrm{SISC}+$ has fulfilled the instructional features of effective teaching. To ensure the effectiveness of guidance, SISC+ has managed to provide positive feedback that can reduce the teacher's guise of any weaknesses and improve performance and work enthusiasm (Sharp et al., 2005). As a teaching coach, SISC+ is able to convince teachers by responding positively and helping to improve teaching quality. Feedback provided by SISC+ fulfills the study conducted by Bhojani (2007), which is the feedback given should be clear and understood by guided individuals.

Studies conducted by Hilmi and Jamil (2017) have proven the same, that SISC+ feedback is at a high level. The situation illustrates that SISC+ has successfully diagnosed teachers' strengths and weaknesses by exploring the problems faced in teaching. This is important because SISC+ needs to know the real situation to ensure the effectiveness of the coaching process as suggested by Gray (2001), Howard (2006) and Marsh et al. (2005). SISC+ can provide oral or written feedback using the Teacher Guidance Matrix (MOE, 2017) as the assessment documentation (Alin \& Turnock, 2007). 
INTERNATIONAL JOURNAL OF ACADEMIC RESEARCH IN PROGRESSIVE EDUCATION AND DEVELOPMENT

Vol. 8, No. 2, 2019, E-ISSN: $2226-6348$ @ 2019 HRMARS

Table 5. Frequency and Percentage for Aspect of Feedback

\begin{tabular}{|c|c|c|c|c|c|c|}
\hline \multirow[b]{2}{*}{ No } & \multirow[b]{2}{*}{ Feedback Aspect } & \multicolumn{5}{|c|}{ Frequency and Percentage (\%) } \\
\hline & & $\mathbf{N}$ & VR & $\mathbf{S}$ & Mt & A \\
\hline 1 & give feedback quickly. & - & $\begin{array}{c}63 \\
(15.8 \%) \\
\end{array}$ & $\begin{array}{c}189 \\
(47.3 \%)\end{array}$ & $\begin{array}{c}115 \\
(28.7 \%) \\
\end{array}$ & $\begin{array}{c}33 \\
(78.3 \%) \\
\end{array}$ \\
\hline 2 & $\begin{array}{l}\text { give encouragement to increase self } \\
\text { confidence to overcome my } \\
\text { weaknesses. }\end{array}$ & - & $\begin{array}{c}16 \\
(4.0 \%)\end{array}$ & $\begin{array}{c}179 \\
(44.8 \%)\end{array}$ & $\begin{array}{c}189 \\
(47.3 \%)\end{array}$ & $\begin{array}{c}16 \\
(4.0 \%)\end{array}$ \\
\hline 3 & $\begin{array}{l}\text { respond well when there is } \\
\text { improvement in the quality of my } \\
\text { teaching. }\end{array}$ & - & $\begin{array}{c}15 \\
(3.8 \%)\end{array}$ & $\begin{array}{c}152 \\
(38.0 \%)\end{array}$ & $\begin{array}{c}174 \\
(43.5 \%)\end{array}$ & $\begin{array}{c}59 \\
(14.8 \%)\end{array}$ \\
\hline 4 & $\begin{array}{l}\text { the feedback provided can be } \\
\text { clearly understood. }\end{array}$ & - & $\begin{array}{c}2 \\
(0.5 \%) \\
\end{array}$ & $\begin{array}{c}162 \\
(40.5 \%)\end{array}$ & $\begin{array}{c}201 \\
(50.2 \%) \\
\end{array}$ & $\begin{array}{c}35 \\
(8.8 \%) \\
\end{array}$ \\
\hline 5 & $\begin{array}{l}\text { encouraged me to think of } \\
\text { alternative alternatives to } \\
\text { implementing the lesson more } \\
\text { effectively. }\end{array}$ & - & $\begin{array}{c}65 \\
(16.3 \%)\end{array}$ & $\begin{array}{c}196 \\
(49.0 \%)\end{array}$ & $\begin{array}{c}129 \\
(32.3 \%)\end{array}$ & $\begin{array}{c}10 \\
(2.5 \%)\end{array}$ \\
\hline 6 & $\begin{array}{l}\text { guide me to explore the potential of } \\
\text { being self-sufficient in order to } \\
\text { improve the quality of teaching. }\end{array}$ & - & $\begin{array}{c}35 \\
(8.8 \%)\end{array}$ & $\begin{array}{c}237 \\
(59.3 \%)\end{array}$ & $\begin{array}{c}122 \\
(30.5 \%)\end{array}$ & $\begin{array}{c}6 \\
(1.5 \%)\end{array}$ \\
\hline \multicolumn{7}{|c|}{ Feedback: Mean 3.43, Standard deviation 0.44} \\
\hline
\end{tabular}

SISC+ personal characteristic as an efficient teaching coaches.

Overall, the majority of respondents' perceptions of SISC+ personal characteristic as teaching guides are at high (mean= 3.52, standard deviation=0.30). The personal nature of SISC+ has fulfilled the instructional features of effective teaching. The findings show that SISC+ has managed to highlight positive personal characteristic and in parallel with the opinion put forward by Knight (2005), that is, the personal characteristic of counselors are as important as the expertise in teaching techniques. The quality of personal characteristic SISC+ can facilitate efforts to establish good relationships with teachers so that teaching guidance can be carried out effectively (Stewart, 2006). SISC+ can also create a conducive atmosphere and successfully increase motivation and maintain the interest of teachers throughout the teaching process.

SISC+ has also fulfilled the features of effective counselors by facing positive challenges and using effective methods of stress (McKinley, 2004). The nature can be clearly illustrated through questionnaire analysis such as SISC+ always patience with teachers' lack of motivation and motivate them to improve work quality. In addition, based on teachers' perceptions, effective guidance features have also been fulfilled by SISC+ based on caring nature and helpfulness in assisting the teaching process and the nature is in line with the opinions expressed by Starcevich (2009). Good personal habits are one of the most important elements of SISC+ in order to produce effective teaching guidance. 
INTERNATIONAL JOURNAL OF ACADEMIC RESEARCH IN PROGRESSIVE EDUCATION AND DEVELOPMENT

Vol. 8, No. 2, 2019, E-ISSN: $2226-6348$ @ 2019 HRMARS

Table 6. Frequency and Percentage of Personal Characteristic

\begin{tabular}{|c|c|c|c|c|c|c|}
\hline \multirow[b]{2}{*}{ No } & \multirow{2}{*}{$\begin{array}{c}\text { Personal Characteristic } \\
\text { Aspects }\end{array}$} & \multicolumn{5}{|c|}{ Frequency and Percentage (\%) } \\
\hline & & $\mathbf{N}$ & VR & $\mathbf{S}$ & Mt & A \\
\hline 1 & easy to refer to at any time. & $\begin{array}{c}1 \\
(0.3 \%) \\
\end{array}$ & $\begin{array}{c}132 \\
(33.0 \%)\end{array}$ & $\begin{array}{c}228 \\
(57.0 \%)\end{array}$ & $\begin{array}{c}36 \\
(9.0 \%) \\
\end{array}$ & $\begin{array}{c}3 \\
(0.80 \%) \\
\end{array}$ \\
\hline 2 & $\begin{array}{l}\text { earnestly helping me with } \\
\text { teaching. }\end{array}$ & - & $\begin{array}{c}5 \\
(1.3 \%) \\
\end{array}$ & $\begin{array}{c}176 \\
(44.0 \%)\end{array}$ & $\begin{array}{c}201 \\
(50.2 \%) \\
\end{array}$ & $\begin{array}{c}18 \\
(4.5 \%) \\
\end{array}$ \\
\hline 3 & $\begin{array}{l}\text { always on time in } \\
\text { implementing guidance. }\end{array}$ & $\begin{array}{c}7 \\
(1.80 \%) \\
\end{array}$ & $\begin{array}{c}137 \\
(34.3 \%)\end{array}$ & $\begin{array}{c}228 \\
(57.0 \%)\end{array}$ & $26(6.5 \%)$ & $\begin{array}{c}2 \\
(0.5 \%) \\
\end{array}$ \\
\hline 4 & $\begin{array}{l}\text { can share ideas with me } \\
\text { related to teaching. }\end{array}$ & $\begin{array}{c}1 \\
(0.3 \%)\end{array}$ & $\begin{array}{c}2 \\
(0.5 \%)\end{array}$ & $\begin{array}{c}146 \\
(36.5 \%)\end{array}$ & $\begin{array}{c}115 \\
(28.7 \%)\end{array}$ & $\begin{array}{c}1 \\
(0.3 \%) \\
\end{array}$ \\
\hline 5 & $\begin{array}{l}\text { do not give up when I do not } \\
\text { reach the desired level. }\end{array}$ & - & $\begin{array}{c}3 \\
(0.8 \%) \\
\end{array}$ & $\begin{array}{c}173 \\
(43.3 \%) \\
\end{array}$ & $\begin{array}{c}205 \\
(51.2 \%) \\
\end{array}$ & $\begin{array}{c}19 \\
(4.8 \%) \\
\end{array}$ \\
\hline 6 & can interact with me properly. & - & $\begin{array}{c}1 \\
(0.3 \%) \\
\end{array}$ & $\begin{array}{c}122 \\
(30.5 \%)\end{array}$ & $\begin{array}{c}203 \\
(50.7 \%)\end{array}$ & $\begin{array}{c}74 \\
(18.5 \%) \\
\end{array}$ \\
\hline 7 & $\begin{array}{l}\text { encouraged me to come up } \\
\text { with ideas for improvement in } \\
\text { teaching. }\end{array}$ & - & $\begin{array}{c}5 \\
(1.3 \%)\end{array}$ & $\begin{array}{c}110 \\
(27.5 \%)\end{array}$ & $\begin{array}{c}189 \\
(47.3 \%)\end{array}$ & $\begin{array}{c}96 \\
(24.0 \%)\end{array}$ \\
\hline 8 & $\begin{array}{l}\text { provide support in improving } \\
\text { my personal weaknesses } \\
\text { relating to teaching. }\end{array}$ & & - & $\begin{array}{c}90 \\
(22.5 \%)\end{array}$ & $\begin{array}{c}231 \\
(57.8 \%)\end{array}$ & $\begin{array}{c}79 \\
(19.8 \%)\end{array}$ \\
\hline 9 & be patient with my nerves. & - & $\begin{array}{c}1 \\
(0.3 \%)\end{array}$ & $\begin{array}{c}85 \\
(21.3 \%)\end{array}$ & $\begin{array}{c}199 \\
(49.8 \%)\end{array}$ & $\begin{array}{c}115 \\
(28.7 \%)\end{array}$ \\
\hline 10 & $\begin{array}{l}\text { appreciate the ideas I give for } \\
\text { teaching improvement. }\end{array}$ & - & $\begin{array}{c}7 \\
(1.8 \%) \\
\end{array}$ & $\begin{array}{c}196 \\
(49.0 \%)\end{array}$ & $\begin{array}{c}181 \\
(45.3 \%)\end{array}$ & $\begin{array}{c}16 \\
(4.0 \%) \\
\end{array}$ \\
\hline 11 & $\begin{array}{l}\text { listen diligently as I put } \\
\text { forward ideas for teaching } \\
\text { improvement. }\end{array}$ & 4 & $\begin{array}{c}4 \\
(1.0 \%)\end{array}$ & $\begin{array}{c}139 \\
(34.8 \%)\end{array}$ & $\begin{array}{c}184 \\
(46.0 \%)\end{array}$ & $\begin{array}{c}73 \\
(18.3 \%)\end{array}$ \\
\hline 12 & $\begin{array}{l}\text { looks comfortable during a } \\
\text { coaching session. }\end{array}$ & - & $\begin{array}{c}25 \\
(6.3 \%)\end{array}$ & $\begin{array}{c}179 \\
(44.8 \%)\end{array}$ & $\begin{array}{c}183 \\
(45.8 \%)\end{array}$ & $\begin{array}{c}13 \\
(3.3 \%)\end{array}$ \\
\hline & Personal characterist & Mean & 2, Stand & deviatic & 0.30 & \\
\hline
\end{tabular}

SISC+ role model level as an efficient teaching coaches.

The results of the analysis found that the majority of respondents' perceptions of SISC+ role model teaching as instructors were at high level (mean= 3.54, standard deviation= 0.74 ). This indicate that SISC+ has been successful in using personal and professional competence to ensure teaching guidance. Positive attitude and good character of SISC+ will be re-applied in the teaching process. Therefore, it will indirectly be an example and role model for the guided teacher. Through SISC+'s practice of giving honest comments and emphasizing work ethics, it will facilitate efforts to attract teachers to provide co-operation in the guidance process. This finding is in line with the study conducted by Shahiran et al. (2016), the counselor needs to be ethical and honest in what is 
said and done. Conducting work professionally by regulating workplace regulations and communicating according to the suitability of time and condition creates a sense of confidence of the teacher towards SISC+. In line with Gholami's (2009) opinion, the moral and intellectual glory inherent in a person, can induce them to do the right thing in the right place at the right time in the right way. The personality highlighted by SISC+ is in line with the profession involved and has professional ethical criteria (Hassani et al., 2006).

Table 7. Frequency and Percentage of Exemplary Aspects of Role Model

\begin{tabular}{|c|c|c|c|c|c|c|}
\hline \multirow[b]{2}{*}{ No } & \multirow[b]{2}{*}{ Role Model Aspect } & \multicolumn{5}{|c|}{ Frequency and Percentage (\%) } \\
\hline & & $\mathbf{N}$ & VR & $\mathbf{S}$ & Mt & A \\
\hline 1 & $\begin{array}{l}\text { confident in carrying out } \\
\text { his duties as a coach. }\end{array}$ & - & $\begin{array}{c}103 \\
(25.8 \%)\end{array}$ & $\begin{array}{c}194 \\
(48.5 \%)\end{array}$ & $\begin{array}{c}97 \\
(24.3 \%)\end{array}$ & $\begin{array}{c}6 \\
(1.5 \%) \\
\end{array}$ \\
\hline 2 & $\begin{array}{l}\text { consider the rules of the } \\
\text { workplace. }\end{array}$ & - & - & $\begin{array}{c}127 \\
(31.8 \%)\end{array}$ & $\begin{array}{c}184 \\
(46.0 \%)\end{array}$ & $\begin{array}{c}89 \\
(22.3 \%) \\
\end{array}$ \\
\hline 3 & $\begin{array}{l}\text { confident in my ability to } \\
\text { carry out my duties as a } \\
\text { teacher. }\end{array}$ & - & $\begin{array}{c}2 \\
(5.0 \%)\end{array}$ & $\begin{array}{c}170 \\
(42.5 \%)\end{array}$ & $\begin{array}{c}201 \\
(50.2 \%)\end{array}$ & $\begin{array}{c}27 \\
(6.8 \%)\end{array}$ \\
\hline 4 & $\begin{array}{l}\text { showing personality that } \\
\text { can convince me. }\end{array}$ & $\begin{array}{c}3 \\
(8.0 \%) \\
\end{array}$ & $\begin{array}{c}141 \\
(35.3 \%)\end{array}$ & $\begin{array}{c}230 \\
(57.5 \%) \\
\end{array}$ & $\begin{array}{c}26 \\
(6.5 \%) \\
\end{array}$ & - \\
\hline 5 & $\begin{array}{l}\text { always focus on working } \\
\text { ethics. }\end{array}$ & - & - & $\begin{array}{c}137 \\
(34.3 \%) \\
\end{array}$ & $\begin{array}{c}248 \\
(62.0 \%) \\
\end{array}$ & $\begin{array}{c}15 \\
(3.8 \%) \\
\end{array}$ \\
\hline 6 & $\begin{array}{l}\text { can be an example to me } \\
\text { as an ethical individual. }\end{array}$ & - & $\begin{array}{c}78 \\
(19.5 \%) \\
\end{array}$ & $\begin{array}{c}192 \\
(48.0 \%) \\
\end{array}$ & $\begin{array}{c}121 \\
(30.3 \%) \\
\end{array}$ & $9(2.3 \%)$ \\
\hline 7 & $\begin{array}{l}\text { memberi komen secara } \\
\text { jujur. }\end{array}$ & - & $\begin{array}{c}1 \\
(0.3 \%)\end{array}$ & $\begin{array}{c}107 \\
(26.8 \%)\end{array}$ & $\begin{array}{c}161 \\
(40.3 \%)\end{array}$ & $\begin{array}{c}131 \\
(32.8 \%)\end{array}$ \\
\hline 8 & $\begin{array}{l}\text { communicate by using } \\
\text { appropriate language } \\
\text { bar. }\end{array}$ & - & $\begin{array}{c}1 \\
(0.3 \%)\end{array}$ & $\begin{array}{c}11 \\
(2.8 \%)\end{array}$ & $\begin{array}{c}170 \\
(42.5 \%)\end{array}$ & $\begin{array}{c}218 \\
(54.5 \%)\end{array}$ \\
\hline 9 & $\begin{array}{l}\text { fostering a sense of } \\
\text { responsibility within me } \\
\text { towards the teaching } \\
\text { profession. }\end{array}$ & & $\begin{array}{c}28 \\
(7.0 \%)\end{array}$ & $\begin{array}{c}256 \\
(64.0 \%)\end{array}$ & $\begin{array}{c}115 \\
(28.7 \%)\end{array}$ & $\begin{array}{c}1 \\
(0.3 \%)\end{array}$ \\
\hline \multicolumn{7}{|c|}{ Level of Role Model: Mean 3.54, Standard deviation 0.74} \\
\hline & er VR $=$ Very Rare $\quad \mathrm{S}=$ & metimes & $\mathrm{Mt}=$ & of the & & vays \\
\hline
\end{tabular}

The conclusions of this study suggest that effective coach is an important element in producing quality SISC+. Each of the aspects that are present in the effective variable of the effective coach (Abiddin, 2006; Bhojani, 2007; Hudson et al., 2005; McAlack, 2006) is considered the prime mover that SISC+ has to master in order to produce quality teachers.

\section{Summary, Suggestions and Implications}

As a conclusion, SISC+ is encouraged to practice effective mentoring features: (1) role as coach, (2) knowledge as coach, (3) feedback provided as coach, (4) personal characteristic as coach, and (5) 
role model as coach. In this regard, this study suggests that: (1) only appoint SISC+ officers who are committed to each task in order to provide full commitment to their teaching guidance, (2) continuously providing training and courses to SISC+ officers for guidance which is done more effectively and the teacher no longer disputes the authority of SISC+. It is important to carefully select qualified an efficient teaching coaches and be given appropriate training (Steiner \& Kowal, 2007) so that the goal of the SISC+ program is fully achieved. This is important because the objectives and goals are the standard of success and failure of a program implemented (Zawawi, 2008).

This study has a positive implication on the quality of SISC+ staff. When viewed as a whole, all the variables in the effective guiding features studied in this study relate to the preparation and skills that SISC+ officers must master to enable them to become quality instructors. Because there is a correlation between the effectiveness of instructional guidance on the quality of teachers produced, then a planned effort to provide exposure to SISC+ officials on every aspect of the practice and approach of teaching guidance should be implemented. The responsibilities of SISC+ staff as instructors are not as easy as changing the behavior and perceptions of teachers requires a long and consistent duration. Researchers also expressed hope that the Ministry of Education, the State Education Department and the District Education Office will play a role in ensuring the implementation of the SISC+ program is at an excellent level.

\section{Acknowledgement}

I sincere acknowledge my Supervisor Assoc. Prof. Dr. Norasmah Othman for her constant support, guidance and encouragement to embark and complete this paper. My sincere acknowledgement to Dr. Nurul Fadly Habidin (UPSI) and her staff for their kind contributions towards completing this paper.

\section{Corresponding Author}

Salefah Mat Salleh, Faculty of Education, Universiti Kebangsaan Malaysia, Malaysia.

Email: salefahms@gmail.com

\section{References}

Abiddin, N.Z. (2006). Effective practice in graduate student supervision using the mentoring and coaching approaches. The Journal of Human Resource and Adult Learning, May 2006.

Syahiran, M., Radzuwan, A. R., Kamariah, Y., \& Safawati Basirah, Z. (2016). Exploring the School Improvement Specialist Coaches' Experience in Coaching English Language Teachers. Arab World English Journal, 7(3), 271-285.

Alin, L. \& Turnock, C. (2007). Assessing Student Performance in Work-based Learning. Making Practice Based Learning work. Retrieved from http://www.practicebasedlearning.org/resources/materials/docs/Assessment\%20in\%20t he\%20Work\%20Place/page_01.htm

Andrews, J. (2002). Workplace Mentoring Guide, Connection State Department of Education, Middletown. Retrieved from http://www.sde.ct.gov/sde/lib/sde/PDF/DEPS/Career/WB/mentoring.pdf. Bhojani, S. (2007). Examining Mentor/Mentee Attribute and the Nature of Feedback at Pre- 
INTERNATIONAL JOURNAL OF ACADEMIC RESEARCH IN PROGRESSIVE EDUCATION AND DEVELOPMENT

Vol. 8, No. 2, 2019, E-ISSN: 2226-6348 @ 2019 HRMARS

Service Professional Development Science Program. Master's Thesis, California State University. Department Science Education.

Bond, T.G. \& Fox, C.M. (2007). Applying the Rasch Model: FundamentalMeasurement in the Human Sciences. Edisi Ke-2. Lawrence Erlbaum Associates, Publisers. Mahwah, New Jersey. London.

Borman, J., \& Feger, S. (2006). Instructional coaching: Key themes from the literature. Providence, RI: The Education Alliance at Brown University.

Boud, D. \& Solomon, N. (2001). Work-based Learning - A new Higher Education. Buckingham: Society for Research into Higher Education and Open University Press, 2001, ISBN 0335 20580.

Chadd, J. \& Anderson, M.A. (2005). Illinois Work-Based Learning Programs: Worksite mentor knowledge and training, career and technical education research, 30(1), pp 25-45. 2005. Retrieved from http://scholar.lib.vt.edu/ejournals/CTER/v30n1/pdf/chadd.pdf.

Cohen, R.J. (2010). Psychological Testing and Assessment: An Introduction to Test and Measurement. Boston: McGraw-Hill Higher Education.

Darling-Hammond, L. (2009). Recognizing and enhancing teacher effectiveness. The International Journal of Educational and Psychological Assessment, 3(1), 1-24.

Denton, C., \& Hasbrouck, J. (2009). A description of instructional coaching and its relationship to consultation. Journal of Educational and Psychological Consultation, 19, 150-175.

Deussen, T., Coskie, T., Robinson, L., Autio, E., \& Institute of Education Sciences (ED), W. (2007). "Coach" can mean many things: Five categories of literacy coaches in reading first. Issues \& answers. REL 2007-No. 005. Regional Educational Laboratory Northwest. Retrieved from ERIC database.

Dole, J. A. (2004). The changing role of the reading specialist in school reform. Reading Teacher, 57(5), 462-471.

Donovan, P., Hannigan, K. \& Crowe, D. (2001). The learning transfer system approach to estimating the benefits of training: empirical evidence. Journal of European Industrial Training 25: 2-4.

Edward, J.K. (2000). The valeu of Co-curricular activities. Retrieved from htttp/www/principals.org.

Erawan, P. (2014). Teacher Training through School-Based Program in Participatory Learning Promotion. Global Conference on Contemporary Issues in Education, GLOBE-EDU 2014, 12 14 July 2014, Las Vegas, USA.

Fatimah, T. (2009). Penilaian pelaksanaan Program Pemulihan Khas di sekolahsekolah rendah di Negeri Selangor daripada perspektif guru besar dan guru pemulihan khas. PhD's Thesis. Fakulti Pendidikan, Universiti Kebangsaan Malaysia.

Fawcett, D.L. (2002). Mentoring - what it is and how to make it work. AORN Journal; 75(5):950954.

Feger, S., Woleck, K., \& Hickman, P. (2004). How to develop a coaching eye. Journal of Staff Development, 25(2), 14-18. Retrieved from ERIC database.

Ferguson, L. (2010). Becoming a mentor, University of Saskatchewan. Retrieved from http://www.usask.ca/nursing/cne/elearning/20100317/Mentoring\%20handout. \%20CNE\%20March\%202010.pdf. 
INTERNATIONAL JOURNAL OF ACADEMIC RESEARCH IN PROGRESSIVE EDUCATION AND DEVELOPMENT

Vol. 8, No. 2, 2019, E-ISSN: 2226-6348 @ 2019 HRMARS

Fisher, R. (2007). Dialogic teaching: developing thinking and metacognition through philosophical discussion. Early Child Development and Care 177 (6-7): 615-631.

Gallucci, C., DeVoogt Van Lare, M., Yoon, I. H., \& Boatright, B. (2010). Instructional coaching: Building theory about the role and organizational support for professional learning. American Educational Research Journal, 47(4), 919-963. Retrieved from https://doi.org/10.3102/0002831210371497

Gholami, K. (2009). Representing the epistemic nature of teachers' practical knowledge: The case of class teachers' general pedagogy. PhD, University of Helsinki.

Gray, M. A., \& Smith, L. N. (2000). The qualities of an effective mentor from the student nurse's perspective: findings from a longitudinal qualitative study. Journal of Advanced Nursing, 32(6), 1542-1549.

Gray, D. (2001). Principles of Assessment and Work-based Learning. In, Berns, R.B. dan Erikson, P.M., (Eds). (2001). Contextual Teaching and Learning. Preparing Students for the New Economy. The Highlight Zone. Research @ Work.

Hallinger, P., \& Kantamara, P. (2000). Educational change in Thailand: Opening a window on to leadership as a cultural process School Leadership \& Management, 20(2), 189-205.

Hargreaves, A. \& Fullan, M. (2000). Mentoring in the new millennium. ProQuest Education Journals, 39 (1), 50-56.

Heineke, S., \& Polnick, B. (2013). Pave the way for coaches: Principal's actions are key to shaping roles and relationships. Learning Forward, 34(3).

Hudson, P., Skamp, K. \& Brooks, L. (2005). Development of an instrument: Mentoring for effective primary science teaching (MEPST). Science Education 89 (4):pp. 657-674.

Howard, K. (2006). How Do we Know what Students have Learned? Retrieved from http://www.howard.k12.md.us/langarts/Curriculum/readassess.htm.

International Reading Association. (2004). The role and qualifications of the reading coaching coach in the United States. Newark, DE: Author.

Jamaliah, A.H., \& Norhashimah, I. (2006). Pengurusan dan kepemimpinan pendidikan: teori, aplikasi dan praktis. Serdang: Universiti Putra Malaysia.

Katzenmeyer, M., \& Moller, G. (2009). Awakening the sleeping giant: Leadership development for teachers. California: Corwin Press.

Knight, J. (2005). A primer on instructional coaches. Principal Leadership, 5(9), 16-21.

Knight, J. (2007). Instructional coaching: A partnership approach to improving instruction. Thousand Oak, CA: Corwin.

Knight, J. (2011). Unmistakable impact. Thousand Oaks, CA: Corwin.

Kwong, I. P. (2001). Motivating student by providing feedback. Motivating student, 4(2). Retrieved from http://www.cdtl.nus.edu.sg/brief/v4n2/default.htm

Knight, J. (2007). Instructional Coaching: A Partnership Approach to Improving Instruction. Thousand Oaks, CA: Corwin Press. Retrieved from https://books.google.com.my

Marsh, S., Cooper, K., Jordan, G., Merrett, S., Scammell, J. dan Clark, V. (2005). Managing Failing Students in Practice. Retrieved from

http://www.practicebasedlearning.org/resources/materials/docs/Failing\%20Students\%20final\%20version\%2022\%20Nov.pdf

McAlack, M.M. (2006). Proteeges' and Mentors' perception and expectation about mentoring in 
INTERNATIONAL JOURNAL OF ACADEMIC RESEARCH IN PROGRESSIVE EDUCATION AND DEVELOPMENT

Vol. 8, No. 2, 2019, E-ISSN: 2226-6348 @ 2019 HRMARS

preparation of youth workers. Temple University.

McKinley, M. (2004). Mentoring matters: creating, connecting, empowering. AACN Clin Issues Adv Pract Acute Crit Care. 2004; 15(2):205-214.

Hilmi, A., \& Jamil, A. (2017). Persepsi Guru Terhadap Program Pembimbing Pakar

Peningkatan Sekolah (SISC+). In Seminar on Transdisciplinary Education (STEd2017) (pp.

198-205). Retrieved from https://sted2017.files.wordpress.com

Ministry of Education Malaysia. (2006). Educational Policy Planning and Research Division.

Pelan Induk Pembangunan Pendidikan. Putrajaya: Bahagian Pembangunan Kurikulum, Kementerian Pendidikan Malaysia.

Ministry of Education Malaysia. (2008). Buku Terma Guru Cemerlang Malaysia.

Ministry of Education Malaysia. (2010). Standard Guru Malaysia. Bahagian Pendidikan Guru.

Ministry of Education Malaysia. (2013). Malaysia Education Blueprint 2013-2015 (Preschool to

Post-Secondary Education). Putrajaya: Ministry of Education Malaysia.

Ministry of Education Malaysia. (2015). Panduan Pengurusan Program Transformasi Daerah

(DTP). Edisi 2.0. Putrajaya: Kementerian Pendidikan Malaysia.

Ministry of Education Malaysia. (2017). Panduan Pengurusan Program Transformasi Daerah

(DTP). Edisi 3.0. Putrajaya: Kementerian Pendidikan Malaysia

Najib, A.G. (2009). Pembinaan dan analisis ujian bilik darjah. Johor Bahru: UTM

Press.

Hassani, S., \& Sani, M. (2006). Kesediaan Profesionalisme Guru Novis: Modul Latihan.

Fakulti Pendidikan, Universiti Kebangsaan Malaysia.

Muijs, D., \& Harris, A. (2007). Teacher leadership in (in) action: three case studies of contrasting schools. Educational Management Administration \& Leadership 35 (1): 111-134.

Natale, C.F., Bassett, K., Gaddis, L., \& McKnight, K. (2013). Creating sustainable teacher career pathways: A 21st century imperative. Retrieved from

http://researchnetwork.pearson.com/wp-ontent/uploads/cstcp_21ci_pk_final_web.pdf

Neufeld, B., \& Roper, D. (2003). Coaching: A strategy for developing instructional capacity-

Promises and practicalities. Washington, DC: Education Matters, Inc.

Nieuwerburgh, C. (2012). Coaching in education: an overview. In C. van Nieuwerburgh (Ed.)

Coaching in Education: Getting Better Results for Students, Educators, and Parents. (pp. 3-

23). London: Karnac.

Nieuwerburgh, C., \& Campbell, J. (2015). A global framework for coaching in education.

CoachEd: The Teaching Leaders Coaching Journal, February 2015: 2-5.

OECD. (2009). Creating Effective Teaching and Learning Environments: First Results from TALIS -

The Professional Development of Teachers. Retrieved from

https://www.oecd.org/berlin/43541636.pdf

Oliva, P. F., \& Pawlas, G. E. (2004). Supervision for today's schools. Hoboken: John Wiley.

Pharrams, V.C. (2016). Instructional Coaches as Teacher Leaders: Roles, Challenges, and Facilitative Factors. Degree of Doctor of Philosophy. Auburn University

Poglinco, S. M., Bach, A. J., Hovde, K., Rosenblum, S., Saunders, M., \& Supovitz, J. A. (2003). The heart of the matter: The coaching model in America's Choice schools. Philadelphia: Consortium for Policy Research in Education.

Ramage, C. (2003). Key Issues on Mentoring Work-Based Learning, CHAIN Workbased Learning 
INTERNATIONAL JOURNAL OF ACADEMIC RESEARCH IN PROGRESSIVE EDUCATION AND

DEVELOPMENT

Vol. 8, No. 2, 2019, E-ISSN: 2226-6348 @ 2019 HRMARS

Event Reading, Institute of Nursing \& Midwifery, Brighton University.

Radhiah, S., Rasid, J., \& Azhar, M. S. (2016). Pengetahuan dan Kefahaman Skop

Pengajaran dan Pembelajaran Bahasa Melayu dalam Kalangan Jurulatih Pakar

Pembangunan Sekolah (SISC+). International Journal of Education and Training (InjET) 2(2)

November: 1- 9.

Russo, A. (2007). School-based coaching: A revolution in professional development or just the latest fad? Harvard Education Letter.

Schmidt E. A., \& Barrett D.C. (2003). Clinical supervision of licensed chemical dependency counselors: a survey of knowledge and practice. Boston, MA: McGraw-Hill.

Sekaran, U. \& Bougie, R. (2011). Research methods for business: a skill-building approach.

Haddington: John Wiley \& Sons Sharp, P., Ainslie, T., Hamphill, A., Hobson, S., Merriman, C., Ong,

P., \& Roche, J. (2005). Mentoring. Retrieved from

http://www.practicebasedlearning.org/resources/materials/docs/Brookes\%20Final.pdf.

Skippington, P. (2002). Good Practice in Workbased Learning; Case Studies of Reframing the

Future Projects, Australian National Training Authority Learning, Melbourne. Retrieved from

http://www.nqf.org.za/download_files/nqfsupport/15\%20Good\%20Practice\%20in\%20Wo rkbased\%20Learning.pdf.

Smith, E., Jr. (2000). Metric development and score reporting in Rasch measurement. Journal of Applied Measurement, 1 (3), 303-326.

Starcevich, M. (2009). Characteristics of the Most Effective Mentors. Resources for Coaching, Teambuilding and Managing Corporate Culture. Center of Coaching and Mentoring. Glyynwood Drive: Bartlesville.

Stewart, D. (2006). Generational mentoring. Jurnal Contin Educ Nurs. 2006; 37(3):113-120.

Steiner, L., \& Kowal, J. (2007). Principal as Instructional Leader: Designing a Coaching Program That Fits. The Center for Comprehensive School Reform and Improvement. Retrieved from www.centerforcsri.org.

Uline, C. L. (2001). The imperative to change. International Journal of Leadership in Education, 4(1), 13-28.

Wren, S. (2005). Literacy coaches: Promises and problems. Paper presented at the National Reading Conference, Miami, Florida.

York-Barr, J., \& Duke, K. (2004). What do we know about teacher leadership? Findings from two decades of scholarship. Review of Educational Research, 74(3).

Zawawi, I. (2008). Penilaian Pelaksanaan Bahasa Kurikulum Kemahiran bertutur Bahasa Arab Komunikasi di sekolah Menengah Kebangsaan Agama. PhD's Thesis. Universiti Kebangsaan Malaysia. 